AnNexin $I$ is a glucocorticoid-induced mediator with anti-inflam matory activity in animal models of arth ritis. We studied the effects of a bioactive annexin $I$ peptide, ac 2-26, dexamethasone (DEX), and interleukin-1 $\beta$ (IL-1 $\beta$ ) on phospholipase $A_{2}\left(P_{2}\right)$ and cyclooxygenase $(\mathrm{COX})$ activities and prostaglandin $\mathrm{E}_{2}$ $\left(\mathrm{PGE}_{2}\right)$ release in cultured human fibroblast-like synoviocytes (FLS). Annex in I binding sites on hum an osteoarthritic (OA) FLS were detected by ligand binding flow cytometry. PLA 2 activity was measured using ${ }^{3} \mathrm{H}$-arachidonic acid release, $\mathrm{PGE}_{2}$ release and COX activity by ELISA, and COX2 content by flow cytometry. Annexin I binding sites were present on human OA FLS. Annexin I peptide ac 2-26 exerted a sign ificant concentration-dependent in hibition of FLS constitutive PLA $\mathrm{P}_{2}$ activity, which was reversed by IL$1 \beta$. In contrast, DEX inhibited IL-1 $\beta$-induced $P L A_{2}$ activity but not constitutive activity. DEX but not annexin $I$ peptide inhibited IL-1 $\beta$-induced $\mathrm{PGE}_{2}$ release. COX activity and $\mathrm{COX} 2$ expression were significantly increased by IL-1 $\beta$. Annexin I peptide demonstrated no inhibition of constitutive or IL$1 \beta$-induced COX activity. DEX exerted a concentration-dependent inhibition of IL- $1 \beta$-induced but not constitutive COX activity. Uncoupling of in hibition of $P_{2} A_{2}$ and COX by annexin $I$ and DEX support the hypothes is that COX is rate-limiting for $\mathrm{PGE}_{2}$ synthesis in FLS. The effect of annexin I but not DEX on constitutive $\mathrm{PLA}_{2}$ activity suggests a glucocorticoidindependent role for annexin $I$ in autoregulation of arachidonic acid production. The lack of effect of annexin $I$ on cytokine-induced $P E_{2}$ production suggests $\mathrm{PGE}_{2}$-independent mechanis $\mathrm{m} s$ for the antiinflam matory effects of an $n$ exin $I$ in vivo.

Key words: Annexin I, Dexamethasone, Synoviocytes, Eicosanoid generation

\section{Annexin I and dexamethasone effects on phospholipase and cyclooxygenase activity in human synoviocytes}

\author{
Annaleise V. Sampey, Paul Hutchinson and \\ Eric F. Morand ${ }^{\mathrm{CA}}$
}

Monash Centre for Inflammatory Diseases, Monash University Department of Medicine, Monash Medical Centre, Clayton, Melbourne, Australia

\author{
${ }^{\mathrm{CA}}$ Corresponding Author \\ Tel: (+61 3) 95943565 \\ Fax: (+61 3) 95943512 \\ Email: eric.morand@med.monash.edu.au
}

\section{Introduction}

Prostaglandins, such as prostaglandin $\mathrm{E}_{2}\left(\mathrm{PGE}_{2}\right)$, mediate the pain and edema associated with arthritis, leading to the widespread use of non-steroidal antiinflammatory drugs in the treatment of arthritis. Within the arthritic synovial lesion, fibroblast-like synoviocytes (FLS) have been implicated as a primary source of $\mathrm{PGE}_{2}{ }^{1}$ In eicosanoid generation, phospholipase $\mathrm{A}_{2}\left(\mathrm{PLA}_{2}\right)$ and cyclooxygenase (COX, or prostaglandin $\mathrm{H}$ synthase) have been described as important regulatory enzymes. The hydrolytic release of arachidonic acid from membrane phospholipids is initiated by $\mathrm{PLA}_{2}$, and arachidonic acid is then catalysed by COX enzymes for the subsequent production of $\mathrm{PGE}_{2}$. $\mathrm{PLA}_{2}$ exists as a secretory group II isoform ( $\left.\mathrm{SPLA}_{2}\right)$ and an arachidonic acid-selective cytosolic form $\left(\mathrm{CPLA}_{2}\right){ }^{2}$ Two isoforms of COX have also been identified: a constitutive (COX1) and a mitogen/ growth factor-inducible (COX2) form. ${ }^{3}$ Studies in a COX2 gene knock-out animal model demonstrate that joint inflammation still persists in the absence of this enzyme. ${ }^{4}$ At present, the enzymatic events responsible for the enhanced production of $\mathrm{PGE}_{2}$ in rheumatoid arthritis (RA) are not fully understood. Knowledge pertaining to which enzyme is rate-limiting in eicosanoid generation in synovium is not fully elucidated. It is known that expression of the $\mathrm{CPLA}_{2}$ and COX2 are increased by interleukin-1 $\beta$ (IL-1 $\beta)^{5,6}$ and that this induction is inhibited by the anti-inflammatory action of dexamethasone (DEX). ${ }^{3,6,7}$

Annexin I (previously known as lipocortin-1) is a 37 kDa protein which belongs to a family of at least 13 structurally related proteins that bind to anionic phospholipids in a $\mathrm{Ca}^{2+}$-dependent manner. ${ }^{8}$ Annexin I was originally defined as a glucocorticoid-inducible inhibitor of $\mathrm{PLA}_{2}$ activity. ${ }^{9}$ The concept that annexin I may modulate its anti-inflammatory actions via cell 
surface binding sites has been suggested from the identification of extracellular annexin I binding sites on peripheral blood leukocytes. ${ }^{10}$ The involvement of annexin $I$ in the regulation of joint inflammation has now been demonstrated in several rat models of arthritis, in which a range of biological actions extending beyond effects on PLA $\mathrm{P}_{2}$ activity has been suggested. ${ }^{11-13}$ The possibility that annexin I has antiinflammatory activity in human arthritis has not been previously explored. We sought to further define the effects of annexin I on $\mathrm{PLA}_{2}, \mathrm{COX}$ and prostaglandin production in human FLS, and use the known $\mathrm{PLA}_{2}$ inhibitory properties of annexin I to investigate the rate-limiting step in synoviocyte prostaglandin production.

\section{Materials and methods}

\section{Materials}

Annexin I ac 2-26 N-terminal derived peptide (acetylAMVSEFLKQAWFIENEEQEYVQTVK ${ }^{14}$ was prepared by use of solid phase step-wise synthesis and obtained from Prof. Milton Hearn (Monash University, Clayton, Australia). Purity was more than $99 \%$ as determined by high-performance liquid chromatography. Annexin I monoclonal antibody $1 \mathrm{~B}$ was produced from hybridoma cultures kindly donated by Dr J Browning, Biogen Inc., Cambridge, USA, and purified using saturated $(50 \%)$ ammonium sulfate precipitation, protein A sepharose affinity chromatography. Affi-Gel 10 was purchased from Bio Rad, Australia. RPMI 1640 solution, sodium bicarbonate $7.5 \%$ solution, penicillin $(5000 \mathrm{IU} / \mathrm{ml}) / \mathrm{streptomycin}(5000 \mu \mathrm{g} / \mathrm{ml})$, L-glutamine and $1 \times$ trypsin/ethylenediaminetetraacetic acid (EDTA) solution were purchased from ICN Biomedicals, USA. Human recombinant IL-1 $\beta$ (specific activity $5.95 \times 10^{7} \mathrm{U} / \mathrm{mg}$ ), DEX, collagenase type II (specific activity $>125 \mathrm{U} / \mathrm{mg}$ ), $[5,6,8,9,11,12,14,15-\mathrm{H}]$ arachidonic acid, bovine serum albumin (BSA) and calcium chloride were purchased from Sigma, Australia. $\left[5,6,8,9,11,12,14,15-{ }^{3} \mathrm{H}\right]$ arachidonic acid (specific activity $212 \mathrm{Ci} / \mathrm{mmol}, 1.0 \mathrm{mCi} / \mathrm{ml}$ ) was purchased from Amersham International plc, Australia. DNase I from bovine pancreas (specific activity $>2000 \mathrm{U} / \mathrm{mg}$ ) and dispase I grade II (specific activity $>0.5 \mathrm{U} / \mathrm{mg}$ ) were purchased from Boehringer Mannheim, Australia. COX2 monoclonal antibody and positive isotype control $\mathrm{mAb}, \mathrm{IgG}_{1}$, were purchased from Transduction Laboratories, USA. Normal human IgG was purchased from CSL Pty Ltd, Australia. Control mAb, $\mathrm{IgG}_{2 \mathrm{a}}$, fluoroisothiocyanate (FITC)-conjugated antimouse IgG was purchased from Silenus, Australia. $\mathrm{PGE}_{2}$ enzyme linked immuno assay (ELISA) kit was purchased from Neogen Corporation, USA. Ultimagold scintillation fluid was purchased from Packard Instrument Company, Australia.

\section{Purification of annexin I protein}

Recombinant human annexin I, a generous gift from Dr Yuko Giga-Hama (Research Centre, Asahi Co. Ltd, Japan), ${ }^{15}$ was purified by affinity gel chromatography, as described by Sakata et al., ${ }^{16}$ using purified monoclonal mouse anti-human annexin I antibody. To confirm purification, samples of purified annexin I dissolved in sample buffer were separated on a $12 \%$ gel using SDS-polyacrylamide gel electrophoresis techniques. A single $37 \mathrm{kDa}$ protein band was detected by western blotting using a specific antiannexin I mAb.

\section{Isolation and culture of FLS}

FLS were obtained from synovium of osteoarthritic (OA) patients $(n=8)$ undergoing joint replacement surgery. All patients satisfied the American College of Rheumatology criteria for the classification of OA. ${ }^{17,18}$ FLS were isolated and cultured as described by Koch. ${ }^{19,20}$ In brief, the synovial-lining tissue was dissected and minced into $2-3 \mathrm{~mm}$ pieces and rotated in $10 \mathrm{ml} / 2 \mathrm{~g}$ of enzyme solution containing $2.4 \mathrm{mg} / \mathrm{ml}$ dispase (grade II, $5 \mathrm{U} / \mathrm{mg}$ ), $1 \mathrm{mg} / \mathrm{ml}$ collagenase (type II) and $1 \mathrm{mg} / \mathrm{ml}$ DNase (type I) in $\mathrm{Ca}^{2+}$ and $\mathrm{Mg}^{2+}$ free Hank's balanced saline solution. FLS were cultured in $10 \mathrm{~cm}$ culture plates in RPMI $10 \%$ foetal calf serum at $37^{\circ} \mathrm{C}$ in a $5 \% \mathrm{CO}_{2}$ humidified incubator. Cells at $3 \mathrm{rd}$ passage were more than $99 \%$ FLS, as demonstrated by dendritic, spindle morphology, and negative staining for the pan-leukocyte antigen $\mathrm{CD} 45$ by flow cytometry. Cells were used between passages 4 and 9. For all experiments, FLS were seeded at $1 \times 10^{5}$ cells per well in 24-well culture plates in RPMI/10\% FCS and allowed to adhere overnight, prior to medium being replaced with RPMI/0.1\% BSA for experimental purposes. This study was approved by the institutional ethics board.

\section{Detection of annexin I binding sites}

FLS were examined using a method that detects specific saturable annexin I binding sites, as described by Perretti $e t a l .^{21}$ Briefly, surface bound annexin I was removed by washing with $1 \mathrm{mM}$ EDTA/PBS. FLS were then washed with $0.1 \% \mathrm{BSA} / \mathrm{phosphate}$ buffered saline (PBS) $/ 1.3 \mathrm{mM} \mathrm{CaCl}_{2}$ and resuspended in $20 \mu \mathrm{l}$ $0.2 \% \mathrm{BSA} / \mathrm{RPMI}$ at $4^{\circ} \mathrm{C}$ and incubated with $0-10 \mu \mathrm{M}$ of human recombinant annexin I. Annexin I binding sites were detected by sequential incubation with $60 \mu \mathrm{g} / \mathrm{ml}$ annexin I monoclonal antibody $1 \mathrm{~B}$ or matched isotype control $\mathrm{mAb} \mathrm{IgG}_{2 \mathrm{a}}$ and FITC-conjugated anti-mouse IgG. Fluorescence was analysed on a MO-FLO flow cytometer (Cytomation, Ft Collins, CO). Cells were gated according to forward and right angle scatter, using 10000 cells for each determination. Each determination was performed in duplicate, with 
annexin I binding represented by mean fluorescence intensity.

\section{Assessment of $\mathrm{PLA}_{2}$ activity}

$\mathrm{PLA}_{2}$ activity in FLS was determined according to Croxtall et al. ${ }^{22}$ Briefly, FLS were incubated for $18 \mathrm{~h}$ with $1 \mu \mathrm{Ci} / \mathrm{ml}\left[{ }^{3} \mathrm{H}\right]$ arachidonic acid in $0.1 \% \mathrm{BSA} /$ RPMI. Cells were treated with $0-100 \mu \mathrm{g} / \mathrm{ml}$ annexin I peptide, $0,0.1 \mathrm{ng} / \mathrm{ml}$ human recombinant IL-1 $\beta$, $10^{-9}-10^{-7} \mathrm{M}$ DEX for $8 \mathrm{~h}$. Triplicate cultures were used for each determination. Radioactivity in the supernatant was determined using a Wallac 1409 liquid scintillation counter (Pharmacia, Finland), with results expressed as tritiated arachidonic acid released, or as a percentage of the mean result of unstimulated cells.

\section{Determination of $\mathrm{PGE}_{2}$ levels}

$\mathrm{PGE}_{2}$ release was determined by assaying treated supernatants, using ELISA. Each determination was performed in duplicate, with results expressed as a percentage of the mean result of the unstimulated cells. The detection limit for this assay was $<0.1 \mathrm{ng} / \mathrm{ml}$.

\section{Assessment of COX activity}

COX activity was measured according to Wilborn et $a l^{7}$ In brief, FLS were incubated for $30 \mathrm{~min}$ with $10 \mu \mathrm{M}$ exogenous arachidonic acid. Supernatants were aspirated and assayed for $\mathrm{PGE}_{2}$ content using ELISA. Duplicate cultures were used for each determination. COX activity was expressed as a percentage of the mean result of the unstimulated cells.

\section{Determination of intracellular COX2}

Intracellular expression of COX2 in FLS was determined using permeabilization flow cytometry, as described by Morand et a . $^{23}$ Briefly, cells were fixed by suspension in $2 \%$ paraformaldehyde/PBS, followed by permeabilization using $0.2 \%$ saponin/PBS. FLS were then sequentially incubated with $20 \mu \mathrm{g} / \mathrm{ml}$ COX $2 \mathrm{mAb}$ (or isotype-matched mAb control, $\mathrm{IgG}_{1}$ ) and FITC-conjugated anti-mouse IgG. Permeabilization of the cells was reversed with PBS. Labelled FLS were analysed using flow cytometry. 10000 cells were used for each determination. Intracellular COX2 protein was expressed as mean fluorescence intensity after subtraction of mean fluorescence intensity obtained with negative control $\mathrm{mAb}$.

\section{Statistical analysis}

Results are expressed as the mean \pm standard error of the mean (SEM). Statistical analysis was performed using the Student's $t$-test, with values of $p<0.05$ regarded as statistically significant.
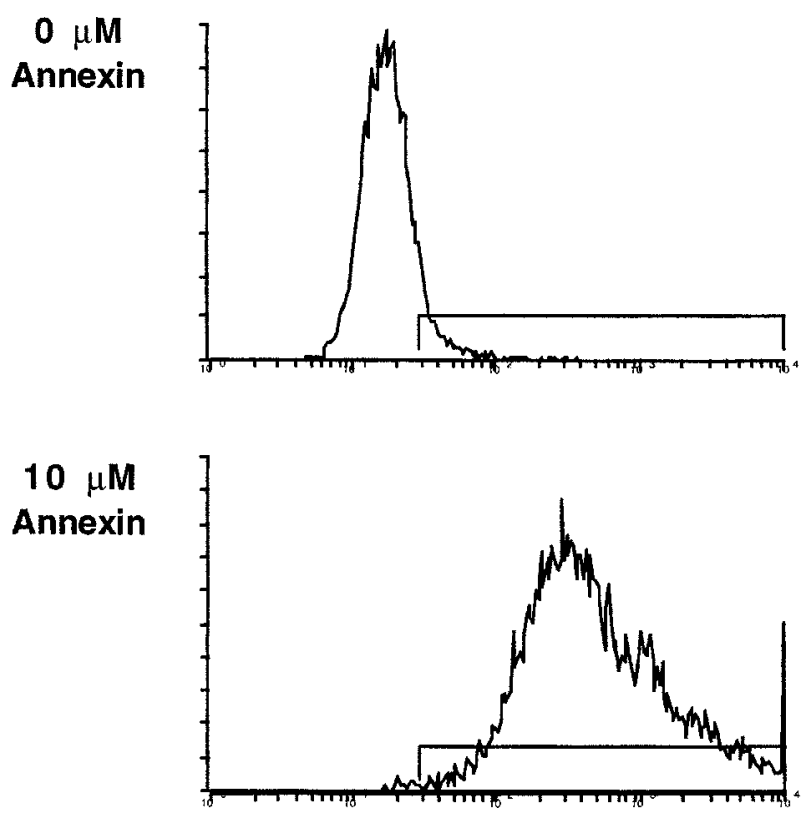

FIG. 1. Fluorescence histograms of annexin I binding sites on human FLS. FLS were incubated with rh annexin I, and annexin I binding detected by flow cytometry after labelling with an anti-annexin ImAb. Representative data obtained using (a) $0 \mu \mathrm{M}$ and (b) $10 \mu \mathrm{M}$ annexin I are depicted. The $x$-axis represents mean fluorescence intensity, and the $y$-axis the relative cell number. Mean data for 6 experiments are provided in Table 1.

\section{Results}

We initially sought to determine the presence of annexin I binding sites on human FLS. Annexin I binding sites as determined by mean fluorescence intensity were detected using a concentration range of annexin I $(0-10 \mu \mathrm{M})$. Results demonstrated concentration-dependent annexin I binding, with more than $99 \%$ of cells demonstrating annexin I binding at $10 \mu \mathrm{M}$ (Fig. 1, Table 1).

To define the effect of annexin I on synoviocyte $\mathrm{PLA}_{2}$ activity, FLS were treated with annexin I $\mathrm{N}$-terminal peptide ac $2-26(0-100 \mu \mathrm{g} / \mathrm{ml})$. Annexin I peptide induced a significant concentration-dependent inhibition of constitutive PLA 2 activity (Fig. 2(a)).

Table 1. Annexin I binding sites on human FLS

\begin{tabular}{lcc}
\hline $\begin{array}{l}\text { Annexin I } \\
\text { concentration } \\
(\mu \mathrm{M})\end{array}$ & $\begin{array}{c}\text { Annexin I } \\
\text { binding } \\
(\%)\end{array}$ & $p$ value \\
\hline 0 & $3.7 \pm 0.5$ & \\
1 & $76.7 \pm 4.2$ & $<0.01$ \\
5 & $97.0 \pm 0.4$ & $<0.01$ \\
10 & $99.5 \pm 0.1$ & $<0.01$ \\
\hline
\end{tabular}

Annexin I binding on FLS was detected using a concentration range of annexin I (0-10 $\mu \mathrm{M})$ and quantitated by flow cytometry. Values are the percentage of cells expressing fluorescence greater than that obtained with a negative control mAb, and are the mean \pm SEM of 6 experiments. All concentrations of annexin I exhibited significant binding $(p<0.01)$ compared to cells incubated without annexin I. 

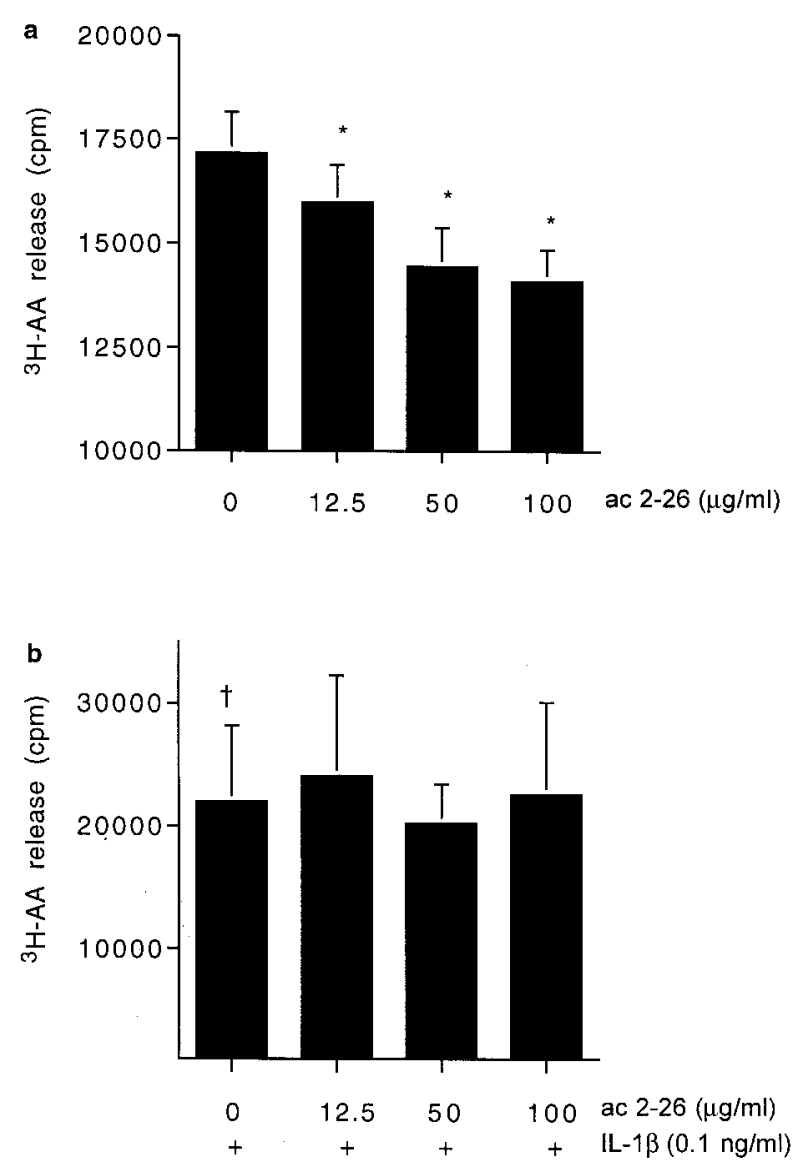

FIG. 2. Effect of annexin I peptide on human FLS PLA activity. FLS were treated with (a) annexin I ac 2-26 $(0-100 \mu \mathrm{g} / \mathrm{ml})$, and/or (b) IL-1 $(0.1 \mathrm{ng} / \mathrm{ml})$ plus annexin I peptide for $8 \mathrm{~h}$. PLA $\mathrm{PL}_{2}$ activity is expressed as ${ }^{3} \mathrm{H}$-AA released. Values are the mean \pm SEM of 8 experiments. ${ }^{*} p<0.05$ versus untreated FLS, $p<0.01$ versus untreated FLS.

Inhibition of $\mathrm{PLA}_{2}$ activity by annexin I was reversed when cells were co-stimulated with IL-1 $\beta$ (Fig. 2(b)).

We subsequently assessed the effects of DEX on synoviocyte PLA ${ }_{2}$ activity. DEX treatment did not

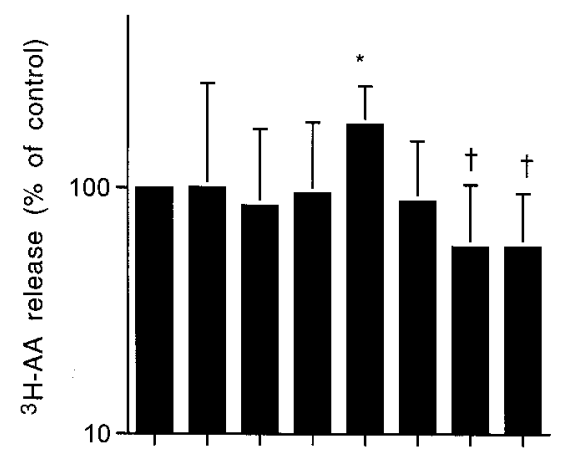

$$
\begin{array}{ccccccccl}
\text { nil } & -9 & -8 & -7 & \text { nil } & -9 & -8 & -7 & \operatorname{DEX}\left(\log _{10} M\right) \\
- & - & - & - & + & + & + & + & \mathrm{IL}-1 \beta(0.1 \mathrm{ng} / \mathrm{ml})
\end{array}
$$

FIG. 3. Effect of DEX on human FLS PLA ${ }_{2}$ activity. FLS were treated with DEX $\left(10^{-9}-10^{-7} \mathrm{M}\right)$, and/or IL-1 $\beta(0.1 \mathrm{ng} / \mathrm{ml})$ for $8 \mathrm{~h}$. PLA $\mathrm{PL}_{2}$ activity $\left({ }^{3} \mathrm{H}\right.$-AA released $)$ is expressed as a percentage of untreated FLS. Values are the mean \pm SEM of 8 experiments. ${ }^{*} p<0.01$ versus untreated FLS, $p<0.05$ versus $\mathrm{IL}-1 \beta$-treated FLS. significantly inhibit constitutive PLA 2 activity over the concentration range $10^{-9}-10^{-7} \mathrm{M}$. In contrast, DEX exerted a significant concentration-dependent reduc-

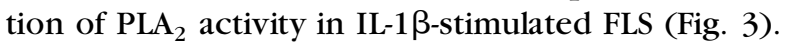

Since annexin I peptide inhibited constitutive PLA $_{2}$ activity, we next determined whether treatment with annexin I peptide affected $\mathrm{PGE}_{2}$ release. Constitutive $\mathrm{PGE}_{2}$ synthesis was detected in FLS. Annexin I peptide did not significantly reduce constitutive $\mathrm{PGE}_{2}$ synthesis (Fig. 4(a)). A significant increase in $\mathrm{PGE}_{2}$ release was observed following IL-1 $\beta$ stimulation $(p=0.001)$, and annexin I peptide did not inhibit IL-1 $\beta$-stimulated $\mathrm{PGE}_{2}$ release. In contrast, DEX had no effect on constitutive $\mathrm{PGE}_{2}$ release but significantly inhibited IL-1 $\beta$-induced $\mathrm{PGE}_{2}$ release in a concentrationdependent manner (Fig. 4(b)).

To further address the differential inhibitory actions of annexin I on $\mathrm{PLA}_{2}$ activity and $\mathrm{PGE}_{2}$ synthesis, studies were designed to evaluate the effects of annexin I peptide and DEX on constitutive and IL$1 \beta$-induced synoviocyte COX activity. Since the synthesis of $\mathrm{PGE}_{2}$ from endogenous arachidonic acid results
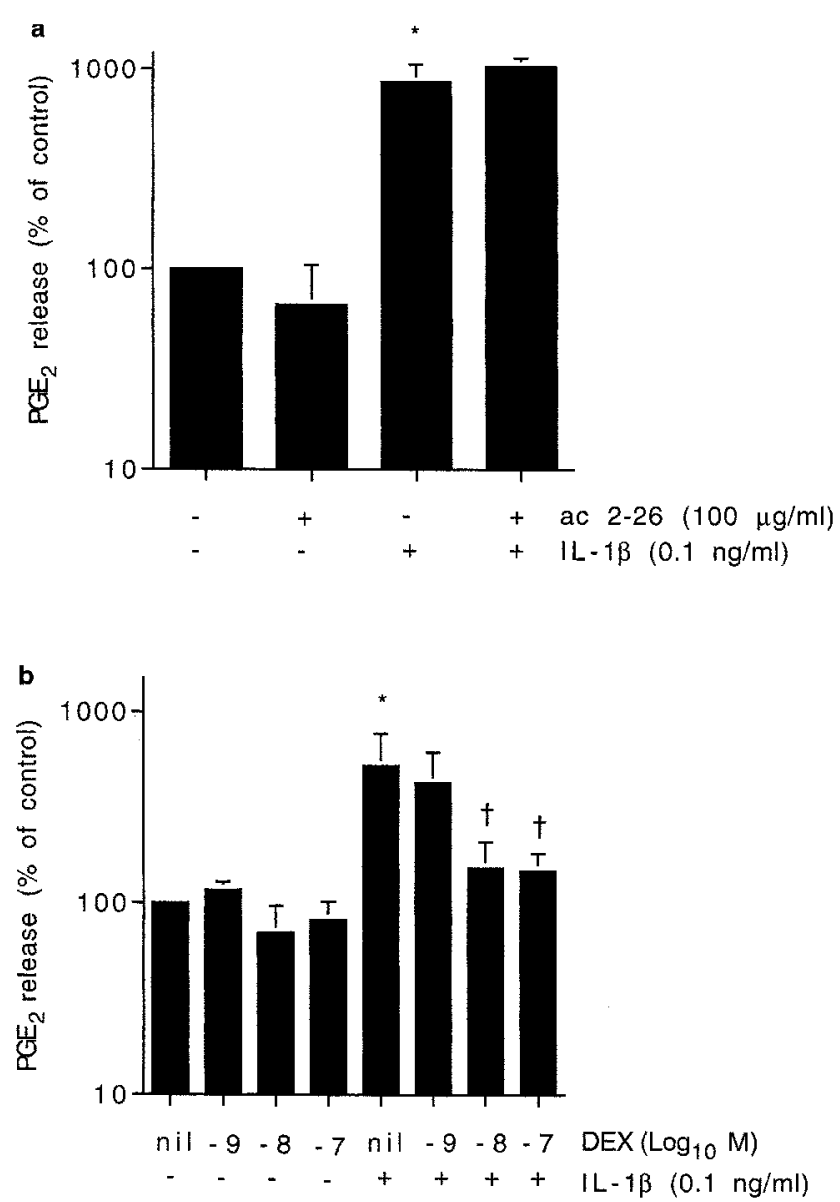

FIG. 4. $\mathrm{PGE}_{2}$ release in human FLS. Human FLS were treated with IL-1 $\beta(0.1 \mathrm{ng} / \mathrm{ml})$, and/or (a) annexin I ac 2-26 $(100 \mu \mathrm{g} / \mathrm{ml})$, (b) DEX $\left(10^{-9}-10^{-7} \mathrm{M}\right)$ for $8 \mathrm{~h}$. $\mathrm{PGE}_{2}$ release was quantitated by assaying supernatants using ELISA and expressed as a percentage relative to untreated FLS. Values are the mean \pm SEM of 4 experiments. ${ }^{*} p<0.01$ versus untreated FLS, $p<0.05$ versus IL-1 $\beta$-treated FLS. 

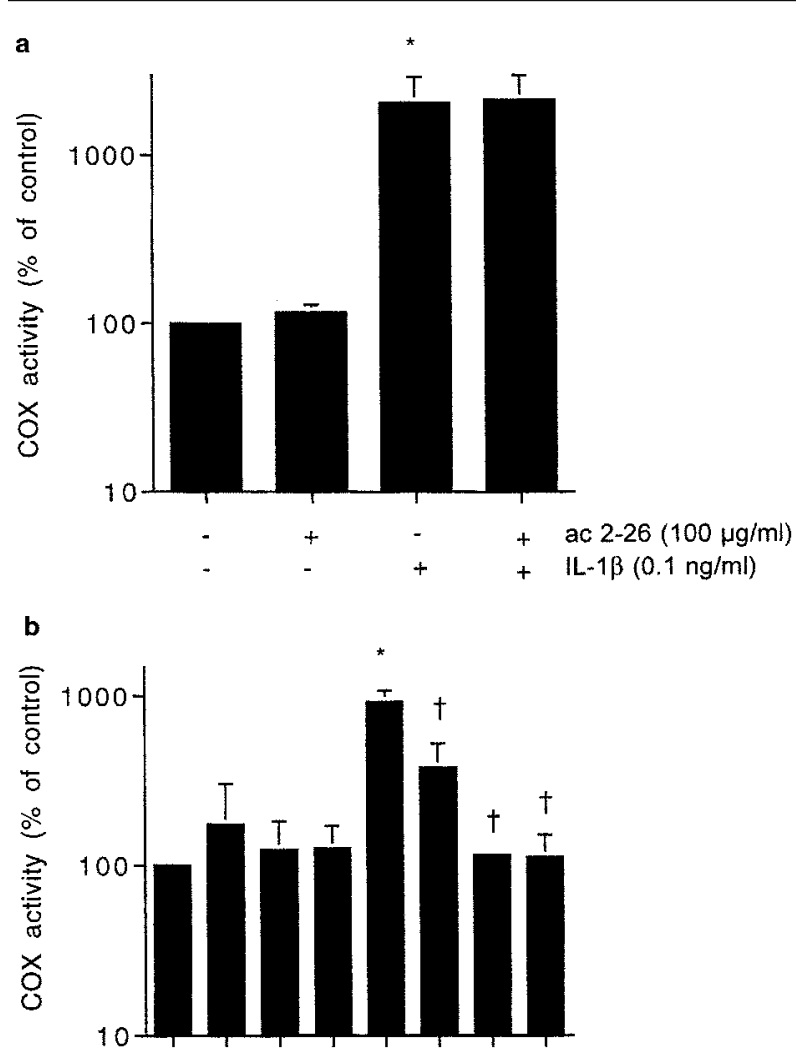

$$
\begin{array}{ccccccccl}
\text { nil }-9 & -8 & -7 & \text { nil } & -9 & -8 & -7 & \text { DEX }\left(\log _{10} M\right) \\
- & - & - & - & + & + & + & + & \mathrm{IL}-1 \beta(0.1 \mathrm{ng} / \mathrm{ml})
\end{array}
$$

FIG. 5. COX activity in human FLS. FLS were treated with IL$1 \beta(0.1 \mathrm{ng} / \mathrm{ml})$, and/or (a) annexin I ac 2-26 $(100 \mu \mathrm{g} / \mathrm{ml})$, (b) DEX $\left(10^{-9}-10^{-7} \mathrm{M}\right)$ for $8 \mathrm{~h}$ and COX activity measured as described. COX activity is expressed as a percentage relative to untreated FLS. Values are the mean \pm SEM of 4 experiments. ${ }^{*} p<0.01$ versus untreated FLS, $p<0.05$ versus IL$1 \beta$-treated FLS.

from the activities of both $\mathrm{PLA}_{2}$ and COX, to estimate

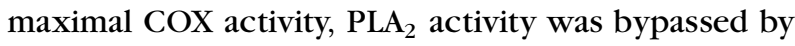
addition of exogenous arachidonic acid. ${ }^{7}$ Low levels of constitutive COX activity were detected in FLS. IL-1 $\beta$ significantly increased COX activity $(p=0.0004)$ (Fig. 5(a)). Annexin I peptide exerted no significant effect on constitutive or IL-1 $\beta$-stimulated COX activity (Fig. 5(a)). DEX exerted no significant effect on constitutive COX activity in DEX treated FLS. In contrast, DEX resulted in a concentration-dependent reduction of IL$1 \beta$-induced COX activity (Fig. 5(b)).

The question of whether modulation of COX activity reflected its intracellular expression was investigated using permeabilization flow cytometry. Constitutive expression of intracellular COX2 protein was detected in FLS, and was increased by IL-1 $\beta$. Annexin I peptide did not demonstrate any significant effect on constitutive or IL-1 $\beta$-stimulated COX2 protein in FLS (Fig. 6(a)). DEX did not significantly inhibit constitutive intracellular expression of COX2. However, DEX exerted a concentration-dependent inhibition of intracellular COX2 expression in IL-1 $\beta$-stimulated FLS (Fig. 6(b)). These results demonstrate consistency between modulation of intracellular expression of COX 2 and its activity.

\section{Discussion}

The hypothesis that annexin I is an anti-inflammatory mediator in arthritis originated from the detection of annexin I in human rheumatoid synovium. ${ }^{24}$ Animal models of arthritis have subsequently demonstrated that annexin has important inhibitory effects in vivo. For example, administration of annexin I peptide substantially inhibited carrageenan-induced arthritis, whilst anti-annexin I antibody exacerbated arthritis severity and reversed the effect of exogenous DEX in this model. ${ }^{12}$ Similarly, exacerbation of disease and increased synovial production of tumour necrosis factor- $\alpha$ and $\mathrm{PGE}_{2}$ were observed in adjuvant arthritic rats administered anti-annexin I antibody. ${ }^{13}$ Moreover, annexin I neutralization reversed the effects of DEX on disease severity in adjuvant $\operatorname{arthritis}^{13}$ and on rat synovial macrophage nitric oxide production. ${ }^{11}$ In human disease, histological studies demonstrate
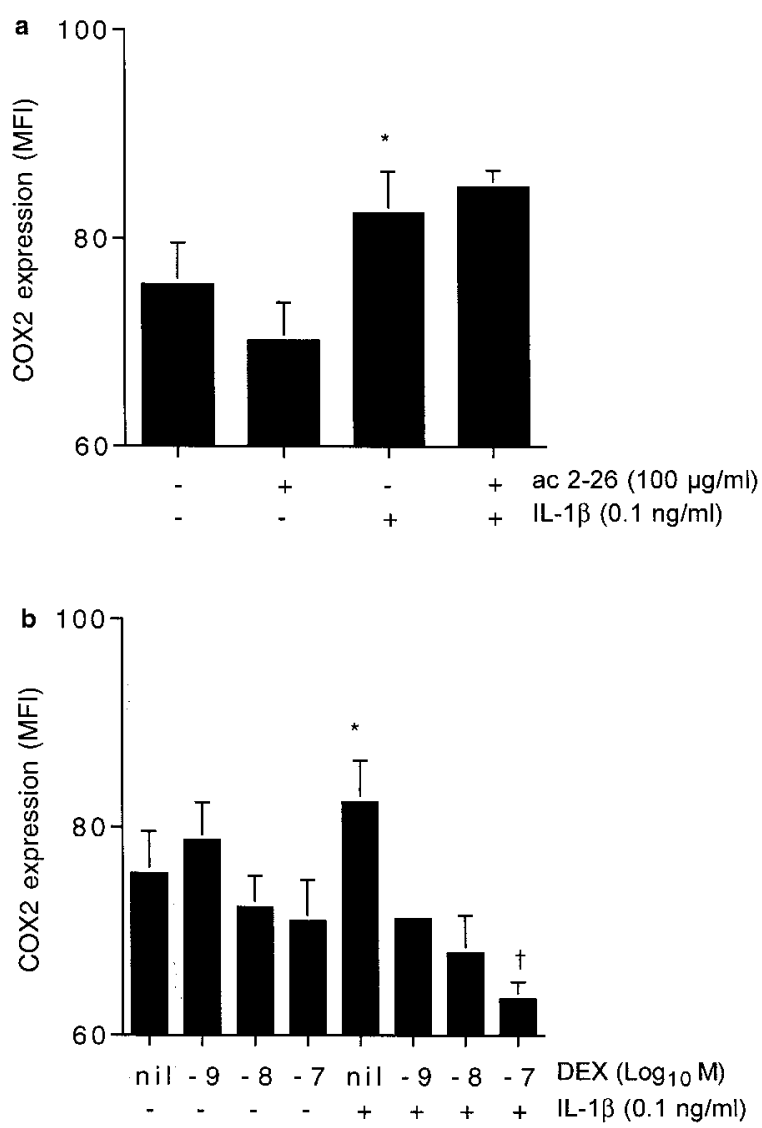

FIG. 6. Intracellular COX2 expression in human FLS. Human FLS were treated with IL-1 $\beta(0.1 \mathrm{ng} / \mathrm{ml})$, and/or (a) annexin I ac $2-26(100 \mu \mathrm{g} / \mathrm{ml})$, (b) DEX $\left(10^{-9}-10^{-7} \mathrm{M}\right)$ for $8 \mathrm{~h}$. Intracellular COX2 was detected by permeabilization flow cytometry and expressed as mean fluorescence intensity (MFI) after subtraction of MFI obtained with the negative control mAb. Values are mean \pm SEM of 4 experiments. ${ }^{*} p<0.01$ versus untreated FLS, $p<0.01$ versus IL- $1 \beta$-treated FLS. 
annexin $I$ in the synovial-lining layer of RA synovium. ${ }^{24}$ Annexin I expression in human peripheral blood leukocytes has been described, with maximal annexin I content in neutrophils and monocytes. ${ }^{23}$ Moreover, altered annexin I biology is seen in subjects with RA, who exhibit reduced numbers of annexin I binding sites on leukocytes compared to controls. ${ }^{25}$ Impaired glucocorticoid induction of annexin I production has also been noted in leukocytes of RA patients, ${ }^{26}$ and RA patients with high titre antiannexin I antibodies exhibit impaired glucocorticoid responsiveness. ${ }^{27}$

Treatment of undifferentiated cells with glucocorticoids increases annexin I transport to the cell surface. ${ }^{28}$ The mechanisms whereby annexin I crosses the membrane are unclear since the protein lacks a signal sequence and is therefore unlikely to access secretory vesicles for release via the conventional method of exocytosis. The translocation of annexin I protein from intracellular stores to cell surface binding sites is believed to be imperative for its function. ${ }^{29,30}$ Certainly, extracellular anti-annexin I antibodies significantly reverse the anti-inflammatory effects of glucocorticoids and simultaneously deplete intracellular cellular annexin $\mathrm{I}^{11,13,31,32}$

Evidence that exogenous annexin I modulates its biological effects through specific cell surface annexin I binding sites originated from the identification of these sites on peripheral blood leukocytes. ${ }^{10}$ Given that annexin I is expressed in RA synovium, it is conceivable that in FLS, annexin I mediates its biological effects via binding to cell surface sites. No previous study has examined the presence of binding sites or the biological function of annexin I in human synovial cells.

The current data establish the presence of annexin I binding sites on human FLS. The factors influencing annexin I binding site expression are unclear, and the absence of molecular identification of the binding site limits study of its regulation. Nonetheless, having established the presence of potentially biologically active annexin I binding sites in FLS, we sought to assess the effect of annexin I on these cells. An annexin I N-terminal peptide of 25 amino acids, annexin I ac 2-26, has been shown to mimic antiinflammatory actions of annexin $\mathrm{I},{ }^{33,34}$ including inhibition of arthritis models. ${ }^{11}$ Perretti et al. have reported that the biological activity of annexin I ac 2-26 is comparable with that of recombinant human annexin I, albeit at a lower molar potency, and that it requires binding to cell surface binding sites to exert its biological effects. ${ }^{34}$

Previous investigations have evaluated the effects of glucocorticoids and cytokines on the regulation of $\mathrm{PLA}_{2}$ and COX at the levels of transcription ${ }^{6,35}$ or translation. ${ }^{36}$ Studies have also compared the level of activity of these enzymes in various cell types, following IL- $1^{37}$ and DEX treatments, ${ }^{7}$ but studies of the rate-limiting step at the enzyme activity level in human FLS have not been undertaken. Our results indicate a significant concentration-dependent inhibition of constitutive but not IL-I $\beta$-induced PLA $\mathrm{P}_{2}$ activity by annexin I ac 2-26. In A549 cells, inhibition of arachidonic acid release by annexin I peptide is believed to be mediated through inhibition of the activation of $\mathrm{CPLA}_{2}$ whereby $\mathrm{CPLA}_{2}$ is not phosphorylated in the presence of annexin $\mathrm{I}^{38}$ Details of how this is accomplished are still uncertain, but binding site-dependent effects of ac 2-26 are unlikely to relate to the previously proposed 'substrate binding' hypothesis for the effects of annexin I on PLA $\mathrm{P}_{2}$. The selective inhibitory action of DEX on IL-1 $\beta$-stimulated but not constitutive $\mathrm{CPLA}_{2}$ transcription and expression has been described in other investigations ${ }^{6,35}$ but is confirmed at the enzyme activity level for the first time in the current study. The uncoupling of the effects of annexin I and glucocorticoids on $\mathrm{PLA}_{2}$ supports the contention that the constitutive antiinflammatory effects of annexin I are only in part related to mediating the effects of glucocorticoids.

As previously demonstrated, constitutive $\mathrm{PGE}_{2}$ synthesis was detected in cultured FLS. Cytokine upregulation of $\mathrm{PGE}_{2}$ synthesis was observed, again consistent with previous findings. ${ }^{6,36,37}$ Annexin I peptide did not demonstrate any significant inhibitory effect on constitutive or IL-1-stimulated $\mathrm{PGE}_{2}$ production. In rat astrocytes, annexin I peptide reduced but did not abolish endotoxin-induced $\mathrm{PGE}_{2}$ release. ${ }^{38}$

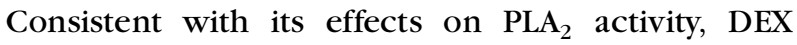
significantly reduced IL-1 $\beta$-stimulated but not constitutive $\mathrm{PGE}_{2}$ release. . $^{7,37,38}$

Annexin I mAb, however, has been observed to reverse the effects of DEX inhibition on $\mathrm{PGE}_{2}$ release, and this study also suggested that glucocorticoid suppression of COX occurs via an annexin I-independent mechanism. ${ }^{39}$

Glucocorticoid-induced suppression of COX2 appears to be independent of annexin $I$ and is almost certainly explained by the direct interaction of the steroid-receptor complex with nuclear factorkappa B. ${ }^{40}$ DEX inhibition of cytokine- or mitogeninduced COX regulation has been previously reported. ${ }^{6,7,41,42}$ In this study, regulation of intracellular COX2 expression was found to be consistent with regulation of its activity, suggesting that the level of COX activity is dependent upon intracellular levels of COX $2 .{ }^{43}$ The differential effects of annexin I peptide and DEX on PLA ${ }_{2}$ activity, COX, and $\mathrm{PGE}_{2}$ production support the hypothesis that $\mathrm{COX}$ is the rate-limiting enzyme in IL- $1 \beta$-induced $\mathrm{PGE}_{2}$ synthesis in FLS. In contrast, the lack of effect of glucocorticoids on constitutive $\mathrm{PLA}_{2}$ and $\mathrm{COX} 2$ activity suggests that annexin I may have a glucocorticoidindependent role in constitutive regulation of $\mathrm{PLA}_{2}$ activity. Biological activity of annexin I peptide has been demonstrated in vivo in rat carrageenan arthri- 
tis, ${ }^{12}$ a model mediated by eicosanoids in addition to nitric oxide and reactive oxygen species. That annexin I peptide has previously been demonstrated to have inhibitory effects on nitric oxide and reactive oxygen species production in other systems highlights the importance of viewing annexin I not solely as an inhibitor of $\mathrm{PLA}_{2}$ activity.

In summary, three novel findings are reported in this study. Firstly, the presence of annexin I binding sites on synoviocytes is demonstrated. Secondly, uncoupling of the effects of annexin I and glucocorticoids on constitutive and cytokine-induced arachidonic acid generation suggests that annexin I has glucocorticoid-independent regulatory activities in inflammation. Our results are consistent with the conclusion that COX2 is the rate-limiting step in synoviocyte $\mathrm{PGE}_{2}$ synthesis, suggesting that $\mathrm{PLA}_{2-}$ directed strategies may not successfully inhibit eicosanoid production in arthritis. Thirdly, the lack of effect of annexin I on $\mathrm{PGE}_{2}$ synthesis, despite clear effects on inflammation in vivo, suggests the antiinflammatory effects of annexin I are eicosanoidindependent. For example, annexin I may influence arachidonic acid-mediated intracellular signal transduction. Arachidonic acid influences activation of the Jun- $\mathrm{N}$ terminal kinase/stress activated protein kinase subgroups of the membrane activated protein kinase family of signal transduction enzymes, via an eicosanoid-independent pathway. ${ }^{44}$ This important pro-inflammatory signal pathway is also influenced by reactive oxygen species, ${ }^{45}$ also known to be inhibited by annexin $\mathrm{I} .{ }^{46}$ The possibility that annexin I modulates inflammation via eicosanoid-independent mechanisms remains to be further investigated. Studies directed at understanding the role of annexin $I$ in such pathways may have therapeutic benefit in the treatment of arthritis.

ACKNOWLEDGEMENTS: The authors acknowledge support from the National Health \& Medical Research Council of Australia (EM).

\section{References}

1. Arend WP, Dayer J-M. Cytokines and cytokine inhibitors or antagonists in rheumatoid arthritis. Arthritis Rheum 1990: 33: 305-15.

2. Murakami M, Nakatani Y, Atsumi G-I, Inoue K, Kudo I. Regulatory functions of PLA . Crit Rev Im m unol 1997: 17: 255-83.

3. Crofford LJ, Wilder RL, Ristimaki AP, et al. Cyclooxygenase-1 and -2 expression in rheumatoid synovial tissues. Effects of interleukin-1, phorbol ester, and corticosteroids. J Clin Invest 1994: 93: 1095-101.

4. Dinchuk JE, Car BD, Focht RJ, et al. Renal abnormalities and an altered inflammatory response in mice lacking cyclooxygenase II. Nature 1995: 378: 406-9

5. Croxtall JD, Newman SP, Choudhury Q, Flower RJ. The concerted regulation of CPLA $A_{2}$, COX2, and lipocortin 1 expression by IL-1_in A549 cells. Biochem Biophys Res Comm 1996: 220: 491-5.

6. Angel J, Berenbaum F, Le Denmat C, Nevalainen T, Masliah J, Fournier C. Interleukin-1-induced prostaglandin $\mathrm{E}_{2}$ biosynthesis in human synovial cells involves the activation of cytosolic phospholipase $A_{2}$ and cyclooxygenase-2. Eur J Biochem 1994: 226: 125-31.

7. Wilborn J, Crofford LJ, Burdick MD, Kunkel SL, Streiter RM, PetersGolden M. Cultured lung fibroblasts isolated from patients with idiopathic pulmonary fibrosis have a diminished capacity to synthesize prostaglandin $\mathrm{E}_{2}$ and to express cylooxygenase-2. J Clin Invest 1995: 95: 1861-8.

8. Flower RJ. Lipocortin. Prog Clin Biol Res 1990: 349: 11-25.
9. Blackwell GJ, Carnuccio R, Di Rosa M, Flower RJ, Parente L, Persico P. Macrocortin: a polypeptide causing the anti-phospholipase effects of glucocorticoids. Nature 1980: 287: 147-9.

10. Goulding NJ, Pan L, Wardwell K, Guyre VC, Guyre PM. Evidence for specific annexin I-binding proteins on human monocytes. Biochem $J$ 1996: 316: $593-7$

11. Yang Y-H, Hutchinson P, Santos LL, Morand EF. Glucocorticoid inhibition of adjuvant arthritis synovial macrophage nitric oxide production: role of lipocortin 1. Clin Exp Imm unol 1998: 111: 117-22.

12. Yang Y-H, Leech M, Hutchinson P, Holdsworth SR, Morand EF. Antiinflammatory effect of lipocortin 1 in experimental arthritis. Infla $m \mathrm{ma}$ tion 1997: 21: 583-96.

13. Yang YH, Hutchinson P, Morand EF Inhibitory effects of annexin I on synovial inflammation in rat adjuvant arthritis. Arthritis Rheum 1999: 42: $1538-44$.

14. Perretti M, Wheller SK, Choudhury Q, Croxtall JD, Flower RJ. Selective inhibition of neutrophil function by a peptide derived from lipocortin-1 N-terminus. Biochem Pharmacol 1995: 50: 1037-42.

15. Giga-Hama Y, Tohda H, Okada H, Owada MK, Okayama H, Kumagai H. High-level expression of human lipocortin 1 in the fission yeast Schizosaccharomyces pombe using a novel expression vector. Biotechnology 1994: 12: 400-4.

16. Sakata T, Iwagami S, Tsuruta Y, Suzuki S, Suzuki R. Study of natural lipocortin 1. A potent mediator for macrophage-mediated immunosuppression in tumor-bearing mice. J Im mu nol 1993: 151: 4964-72.

17. Altman R, Alarcon G, Appelrouth D, et al. The American College of Rheumatology criteria for the classification and reporting of osteoarthritis of the hip. Arthritis Rheum 1991: 34: 505-14.

18. Altman R, Asch E, Bloch $\mathrm{D}$, et al. Development of criteria for the classification and reporting of osteoarthritis. Classification of osteoarthritis of the knee. Arthritis Rheum 1986: 29: 1039-49.

19. Koch AE, Polverini PJ, Leibovich J. Stimulation of neovascularization by human rheumatoid synovial tissue macrophages. Arthritis Rheum 1986: 29: 471-9.

20. Leech M, Metz CN, Hall P, et al. Macrophage migration inhibitory factor (MIF) in rheumatoid arthritis: evidence for pro-inflammatory function and regulation by glucocorticoids. Arthritis Rheum 1999: 42: 1601-8.

21. Perretti M, Flower RJ, Goulding NJ. The ability of murine leukocytes to bind lipocortin 1 is lost during acute inflammation. Biochem Biophys Res Comm 1993: 192: 345-50.

22. Croxtall JD, Choudhury Q, Tokomuto H, Flower RJ. Lipocortin-1 and the control of arachidonic acid release in cell signalling. Biochem Pharmacol 1995: 50: 465-74.

23. Morand EF, Hutchinson P, Hargreaves A, Goulding NJ, Boyce NW. Detection of intracellular lipocortin-1 in human leukocyte subsets. Clin Immunol Imm unopathol 1995: 76: 195-202.

24. Goulding NJ, Dixey J, Morand EF, et al. Differential distribution of annexins -I, -II, -IV, and -VI in synovium. Ann Rheum Dis 1995: 54: 841-5.

25. Goulding NJ, Jefferiss CM, Pan L, Rigby WFC, Guyre PM. Specific binding of lipocortin 1 (annexin I) to monocytes and neutrophils is decreased in rheumatoid arthritis. Arthritis Rheum 1992: 35: 1395-7.

26. Morand EF, Jefferiss CM, Dixey J, Mitra D, Goulding NJ. Impaired glucocorticoid induction of mononuclear leukocyte lipocortin-1 in rheumatoid arthritis. Arthritis Rheum 1994: 37: 207-11.

27. Podgorski MR, Goulding NJ, Hall ND, Flower RJ, Maddison PJ. Autoantibodies to lipocortin-1 are associated with impaired glucocorticoid responsiveness in rheumatoid arthritis. J Rheumatol 1992: 19: $1668-71$.

28. Solito E, Nuti S, Parente L. Dexamethasone-induced translocation of lipocortin (annexin) 1 to the cell membrane of U-937 cells. $\mathrm{Br} J$ Pharmacol 1994: 112: 347-8.

29. Taylor AD, Cowell AM, Flower RJ, Buckingham JC. Lipocortin-1 mediates an early inhibitory action of glucocorticoids on the secretion of ACTH by the rat anterior pituitary gland in vitro. Neuroendocrinology 1993: 58: 430-9.

30. Christian HC, Taylor AD, Flower RJ, Morris JF, Buckingham JC. Characterization and localization of lipocortin 1-binding sites on rat anterior pituitary cells by fluorescence-activated cell analysis/sorting and electron microscopy. Endocrinology 1997: 138: 5341-51.

31. Duncan GS, Peers SH, Carey F, Forder R, Flower RJ. The local antiinflammatory action of dexamethasone in the rat carrageenan edema model is reversed by an antiserum to lipocortin 1 . Br J Pharma col 1993: 108: $62-5$.

32. Croxtall JD, Flower RJ. Lipocortin 1 mediates dexamethasone-induced growth arrest of the A549 lung adenocarcinoma cell line. Proc Natl Acad Sci USA 1992: 89: 3571-5.

33. Cirino G, Cicala C, Sorrentino L, et al. Anti-inflammatory actions of an N-terminal peptide from human lipocortin 1. Br J Pharm a col 1993: 108: 573-4.

34. Perretti M, Ahluwalia A, Harris JG, Goulding NJ, Flower RJ. Lipocortin-1 fragments inhibit neutrophil-dependent edema in the mouse. Im m unol 1993: 151: 4306-14

35. Newton R, Kuitert LM, Slater DM, Adcock IM, Barnes PJ. Cytokine induction of cytosolic phospholipase $A_{2}$ and cyclooxygenase-2 mRNA is suppressed by glucocorticoids in human epithelial cells. Life Sci 1997: 60: $67-78$. 
36. Hulkower KI, Wertheimer SJ, Levin W, et al. Interleukin-1b induces cytosolic phospholipase $\mathrm{A}_{2}$ and prostaglandin $\mathrm{H}$ synthase in rheumatoid synovial fibroblasts. Arthritis Rhe um 1994: 37: 653-61.

37. Szczepanski A, Moatter T, Carley WW, Gerritsen ME. Induction of cyclooxygenase II in human synovial microvessel endothelial cells by interleukin-1. Inhibition by glucocorticoids. Arthritis Rheum 1994: 37: 495-503.

38. Pistritto G, Mancuso C, Traingali G, Perretti M, Preziosi P, Navarra P. The relative contribution of constitutive and inducible cyclooxygenase activity to lipopolysaccharide-induced prostaglandin production by primary cultures of rat hypothalamic astrocytes. Neurosci Lett 1998 246: 45-8.

39. Newman SP, Flower RJ, Croxtall JD. Dexamethasone suppression of IL 1_-induced cyclooxygenase 2 expression is not mediated by lipocortin-1 in A549 cells. Biochem Biophys Res Comm 1994: 202: 931-9.

40. Barnes PJ, Karin M. Nuclear factor-kappa B: a pivotal transcription factor in chronic inflammatory diseases. NEngl J Med 1997: 336: 1066-71.

41. Kujubu DA, Herschman HR. Dexamethasone inhibits mitogen induction of the TIS10 prostaglandin synthase/cyclooxygenase gene. J Biol Chem 1992: 267: 7991-4.
42. Masferrer JL, Zweifel BS, Seibert K, Needleman P. Selective regulation of cellular cyclooxygenase by dexamethasone and endotoxin in mice. $J$ Clin Invest 1990: 1375: 1379.

43. Kujubu D, Reddy S, Fletcher B, Herschman H. Expression of the protein product of the prostaglandin synthase-2/TIS10 gene is mitogen-stimulated Swiss 3T3 cells. J Biol Chem 1993: 268: 5425-30.

44. Rizzo MT, Carlo-Stella C. Arachidonic acid mediates interleukin-1 and tumor necrosis factor-a-induced activation of the c-jun amino-terminal kinases in stromal cells. Blood 1996: 88: 3792-800.

45. Cui XL, Douglas JG. Arachidonic acid activates c-jun N-terminal kinase through NADPH oxidase in rabbit proximal tubular epithelial cells. Proc Natl Acad Sci USA 1997: 94: 3771-6.

46. Maridonneau-Parini I, Errasfa M, Russo-Marie F. Inhibition of $\mathrm{O}_{2}$ - generation by dexamethasone is mimicked by lipocortin-1 in alveolar macrophages. J Clin Invest 1989: 83: 1936-40.

Accepted after revision 17 May 2000 


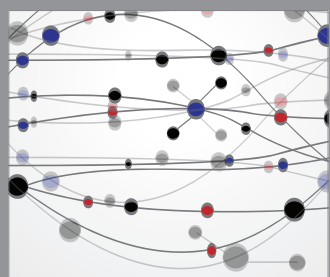

The Scientific World Journal
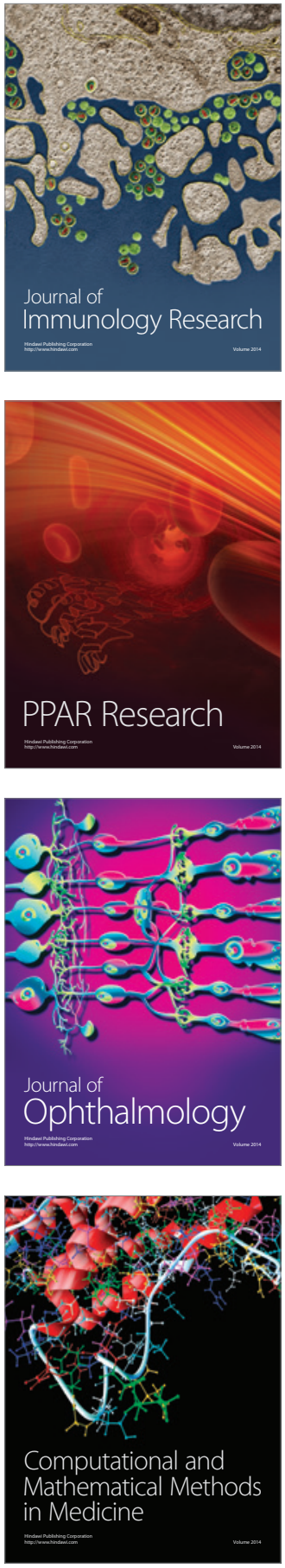

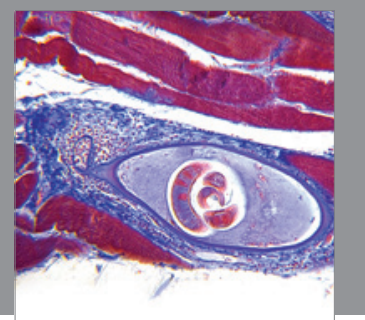

Gastroenterology

Research and Practice
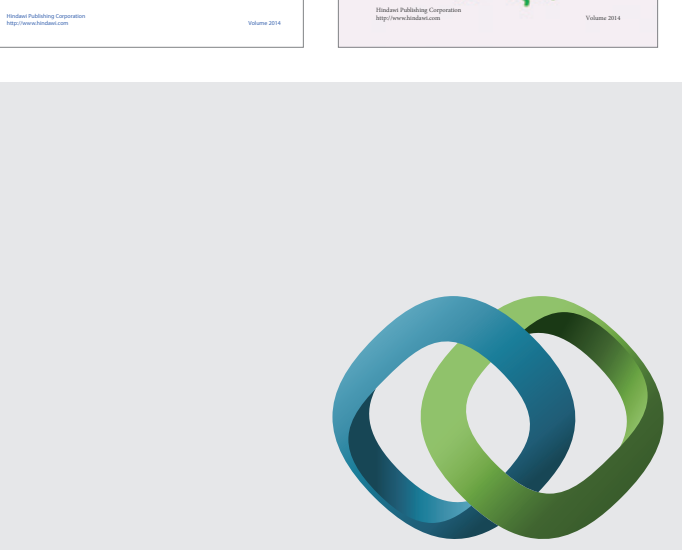

\section{Hindawi}

Submit your manuscripts at

http://www.hindawi.com
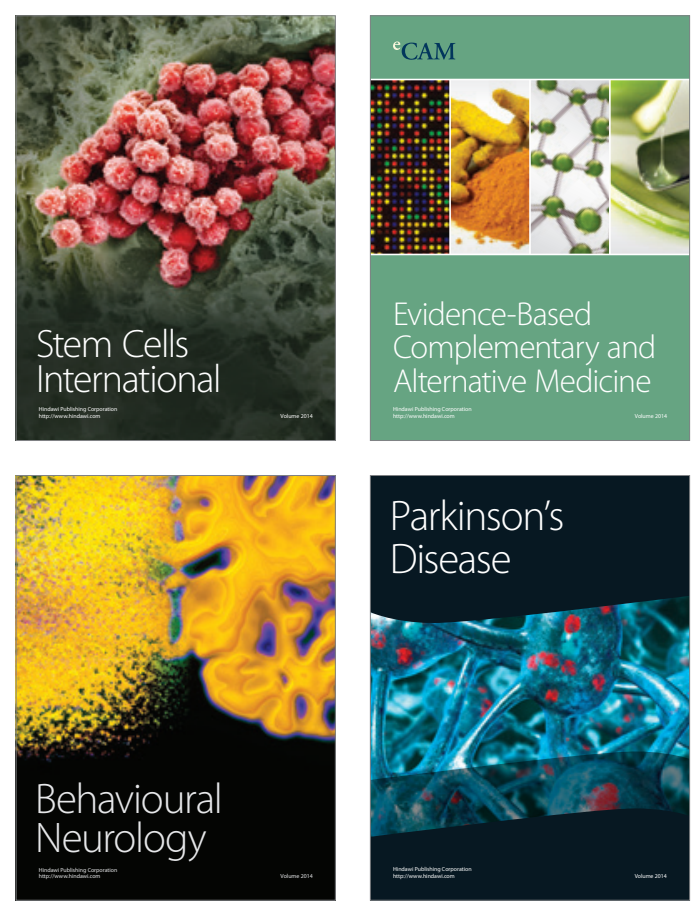

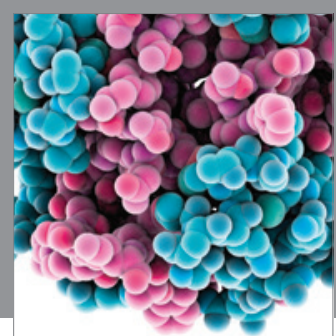

Journal of
Diabetes Research

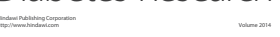

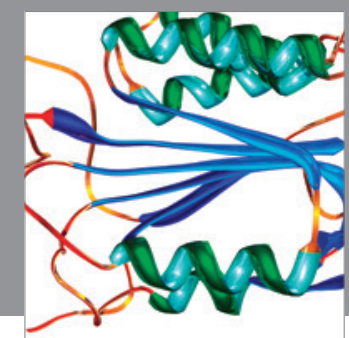

Disease Markers
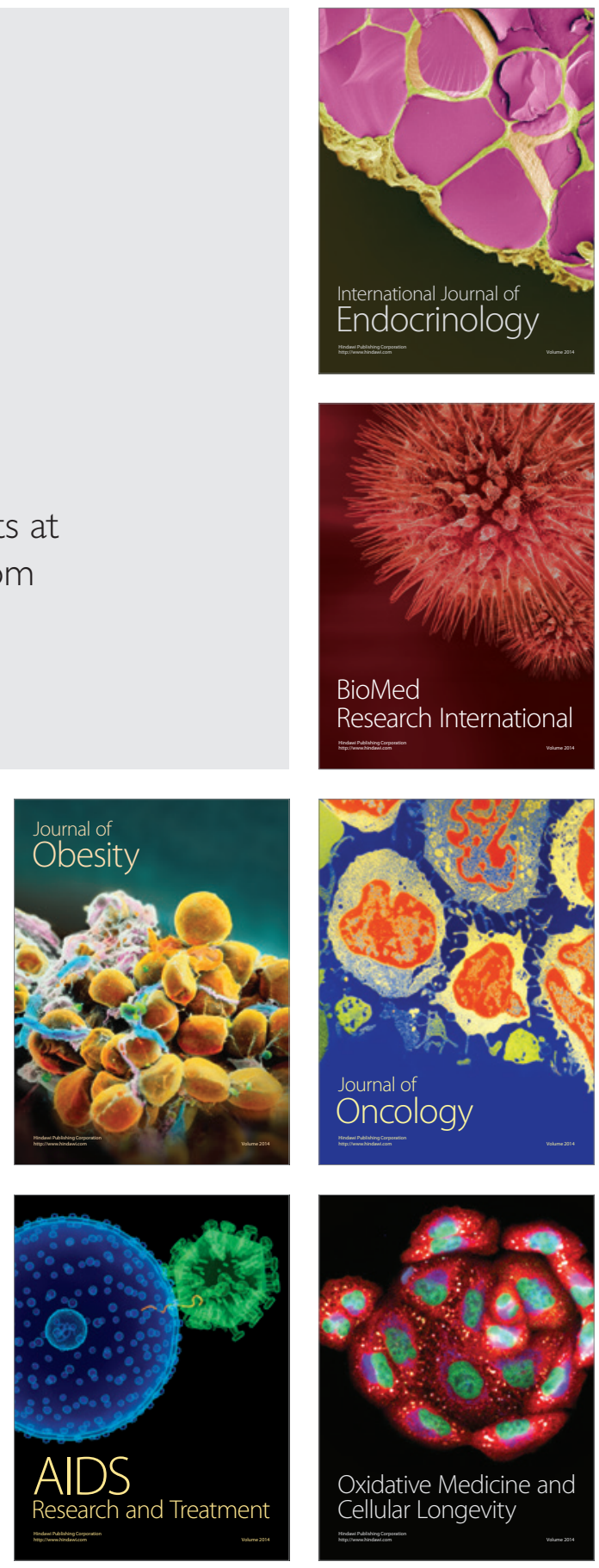